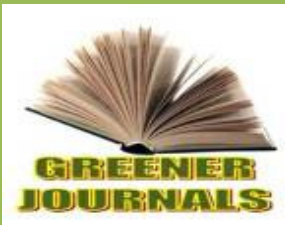

\title{
Effect of different Organic Manures and Mineral NPK Fertilizer on Maize Yield on Volcanic Soils of the Mt Cameroon area under Minimum Tillage
}

\author{
Amet Sallah, Asongwe Godswill Azinwie*, \\ Nkwelle Jerome Alobwede, Fru Delvis Ngang
}

Department of Development Studies, Pan African Institute for Development -West Africa (PAIDWA) Buea Cameroon. P. O. Box 133 Buea Cameroon.

\section{ARTICLE INFO}

Article No.: 051617062

DOI: 10.15580/GJAS.2017.4.051617062

Submitted: $16 / 05 / 2017$

Accepted: 24/05/2017

Published: 19/06/2017

*Corresponding Author

Asongwe Godswill Azinwie

E-mail: asongwe2003@gmail. com

Phone: 237674663304

Keywords:

Soil, Organic Manures, NPK

Fertilizer, Maize growth and Yield
Today, agriculture is characterized by low yields due to continuous cropping and subsequent mining of nutrients without adequate external additions. The study was conducted to examine the effects of different organic manures and mineral fertilizer input on maize grown on volcanic soil of the Mt Cameroon area under minimum tillage. It specifically a) characterize the soils of the area, b) evaluates the physiological growth responses of maize under different external inputs, c) determines their yield responses. An experiment was laid out in randomized complete block design with four replications where maize of the Acid Tolerate Population (ATP) variety was planted. Soil samples were obtained from three different locations on each plot. The samples were analyzed for their physicchemical properties using standard methods. The maize was evaluated for growth and yield. The data was subjected to descriptive and inferential statistics. The soils of the area were slightly acidic with an average $\mathrm{pH}$ value of 6.1 . The concentration of calcium and magnesium were low $(3.70 \mathrm{cmol}(+) / \mathrm{kg})$ and medium $1.12 \mathrm{cmol}(+) / \mathrm{kg}$ ), respectively. The average nitrogen content of the soils was very low $(0.18 \%)$ just as the $\mathrm{C} / \mathrm{N}$ ratio. Poultry manure fertilization gave the highest yield of $1.4 \mathrm{t} \mathrm{ha}^{-1}$ and the maximum harvest index (17.8\%) while the lowest harvest index of $13.60 \%$ was recorded in plot where no manure was applied (control). The study, concludes that though organic manures are hailed for their soil amendment properties, the type and duration of handling plays a great role in nutrient availability to plants. 


\section{BACKGROUND}

Low activity clays characterize tropical soils and the magnitude of nutrient depletion especially in Africa's agricultural is enormous (Stoorvogel and Smaling, 1990). This depletion of soil fertility is widely recognized as the major cause of low food crop production in subSaharan Africa (Sanchez, 2002). Low-quality resources tend to have a period of nutrient immobilization and the subsequent release of inherent nutrients does not match crop demand (Palm et al. 1997; Vanlauwe et al., 2005).

External fertlising agents to agricultural production systems include mineral fertilisers such as urea, ammonium nitrate, sulfates, and phosphates; organic fertilisers such as animal manures, composts, and biosolids. The use of mineral fertilizers in subSaharan Africa is limited by the lack of purchasing power and scarcity of the product in the smallholder sectors while their continuous use can also lead to a decline in soil organic manure (SOM) by enhancing its decomposition (Giller et al., 2009), making SOM a critical nutrient source.

The South West Region of Cameroon has one of the highest yield potential for maize production in Cameroon (MINEPAT, 2008). However, the latter noted that in the Region, actual average yields of maize are still low (1.67 tons/ha) as compared to the potential yields of 6 tons/ha). Driven by a rapid rise in petroleum prices and a rapid global expansion of biofuel production from maize (Cassman, 2007), the price of maize rose by over $50 \%$ from 20012007 (FAO, 2008), and the demand for maize is estimated to double in the next half century (Gowing and Palmer 2008). Maize production suffers from a number of constraints, which include diseases, insect pests, and decline in soil fertility, environmental degradation and weeds in infestation (MINEPAT, 2008).

The release of nutrients and the efficiency of nutrient availability to the plant can be manipulated by controlling the quality and quantity of SOM, which can facilitate the retention of added mineral fertilizers and the timing of their availability (Baudeon et al., 2007).

Organic manure improves soil fertility by influencing its physical, chemical and biological properties. It improves water circulation and soil aeration, and increases the soil moisture holding capacity (Soltner, 1985). Whereas, mineral fertilizers are used to supplement the natural soil nutrient supply in order to satisfy the demand of crops with a high yield potential and produce economically viable yields.

The major pathways of soil fertility decline on farmlands include the loss of nutrients through erosion, leaching, volatilization, crop uptake and harvest without the corresponding replenishment. Soil nutrients replenishment is therefore a prerequisite for halting soil fertility decline. This may be accomplished through the application of mineral and organic fertilizers. Studying the effect of different fertilizers is a key entry point for sustainable agricultural productivity hence improving food production, which is a major constraint in the world.
Furthermore, in most areas, soils are excessively tilled. Tilled soils are vulnerable to erosion (both wind and water) which does not only sweeps off fertile surface soils but also allows the environment in an appalling condition. In order to conserve the environment side-by-side improves food production, conservation agriculture is preached but the level of application has not well been investigated into in many parts of the world. It is hypotheized that under minimum tillage, maize does not respond differently to fertilizing agents. The main objective of the study is to examine the effects of different organic manure and mineral fertilizer inputs on maize yield.

This study examines the effects of different organic manures and mineral NPK fertilizer inputs on maize yield under minimum tillage conditions. It specifically a) evaluates the physiological growth responses of maize under different fertilizer applications, b) determines the maize yield response to mineral and organic fertilizers application.

\section{MATERIAL AND METHODS}

\subsection{Site Location}

The study was conducted in April to July 2016 at the Research farm of the Pan African Institute for Development West Africa (PAID-WA) Buea, South West Region of Cameroon. The South West Region has an estimated population of 1.3 million inhabitants, covering a surface area of $24,923 \mathrm{~km}^{2}$ and a population density of about 75 inhabitants $/ \mathrm{km}^{2}$. The area lies within the tropical rainforest belt, latitude $4.09-5^{\circ} \mathrm{N}$ of the equator and longitude 8 and $10^{\circ} \mathrm{E}$ of the Greenwich meridian (MINEPAT, 2008). The mean annual temperature is $28^{\circ} \mathrm{C}$ while the annual rainfall stands at about $2.000 \mathrm{~mm}$, most of which is received between June and September (Ndam et al., 1998). The relative humidity averages 70 $80 \%$ while the annual sunshine lies between 9001200 hours. The soil type is basically volcanic (Cable and Cheek, 1998) making it suitable for agriculture.

\subsection{Land preparation and sowing}

Sowing was done by dibbling method (by placing 2 seeds manually at $30 \mathrm{~cm}$ intra-row and $60 \mathrm{~cm}$ inter-row. Herbicide was initially used to destroy the weeds emergent in the trials and suppressed the dominant of weed on the trials. Manual weed control was practiced to keep the field weed free.

\subsection{Experimental layout and management}

The land was developed under minimum tillage on a plot measuring sixteen meters square (16m2). This was further divided into four plots of four by four meters $(4 \times 4 \mathrm{~m})$. Experiment was laid out in randomized complete block design with four replications. A maize variety, Acid 
Tolerate Population (ATP), commonly grown by farmers in the area was planted at a spacing of 50 and $50 \mathrm{~cm}$ inter and intra-row, respectively. Three seeds were sown per hole to a depth of about $3 \mathrm{~cm}$ and thinned to two (2) maize plants at 3-4 leaf stages. This gave a total of 40 000 plants per hectare. Three external soil fertility amendment inputs ((1) poultry manure (10t/ha), (2) pig manure (10t/ha) (3) NPK 20:10:10 of $3 \mathrm{~g}$ per plant stand ha were applied to give an equivalent of $60 \mathrm{~kg} \mathrm{~N}$ per ha. These quantities have been recommended by FURP (1987) to supply $N$ that meets maize nutrient requirement for an optimum crop production. In all, there were four treatments with one of them, the control. The organic materials were incorporated into the soil two weeks before sowing while NPK was applied immediately after thinning.

Before external inputs fertilizer application and sowing of crop, soil samples were obtained from three different locations on each plot, having equal sections, with the help of a hand trowel to a depth of $20 \mathrm{~cm}$ to ascertain the background situation of soil physic chemical properties for the purpose of standard soil fertility assessment at the Environmental and Analytical Chemistry Laboratory of the University of Dschang, Cameroon. Samples were pooled to make a composite sample. The samples were air-dried sieved through a 2 $\mathrm{mm}$ sieve. Particle size distribution, cation exchange capacity (CEC), exchangeable bases, electrical conductivity (EC) and $\mathrm{pH}$ were determined by standard procedures (Pauwels et al., 1992). Soil pH was measured both in water and $\mathrm{KCl}$ (1:2.5 soil/ water mixture ) using a glass electrode $\mathrm{pH}$ meter. Part of the soil was ball-milled for organic carbon (OC) (Walky and Black method) and Kjeldahl- $\mathrm{N}$ as largely described by Pauwels et al. (1992). Available P was determined by Bray II method. Exchangeable cations were extracted using $1 \mathrm{~N}$ ammonium acetate at $\mathrm{pH}$ 7. Potassium (K) and sodium $(\mathrm{Na})$ in the extract were determined using flame photometer and magnesium $(\mathrm{Mg})$ and calcium (Ca) were determined by complexiometric titration. Apparent $\mathrm{CEC}$ (CEC at $\mathrm{pH} 7$ ) was determined directly as outlined by Pauwels et al. (1992). Chemical analysis of poultry manure was carried out before its application

\subsection{Vegetative characteristics measured}

Growth parameters data were taken as from the third week after emergence. This was obtained from four inner plants from each experimental plot leaving out the guard rows. The plants were randomly selected. The plants were tagged to ease identification (Figure 1 and $2)$. The plant height $(\mathrm{cm})$ was measured every two weeks using a flexible tape rule from the base to the apex of the stem. Number of leaves was assessed by visual count of the green leaves at the same intervals. Stem base diameter $(\mathrm{mm})$ was measured in between the 1st and the 2nd internodes by use of micrometer screw gauge in all the experimental plots.

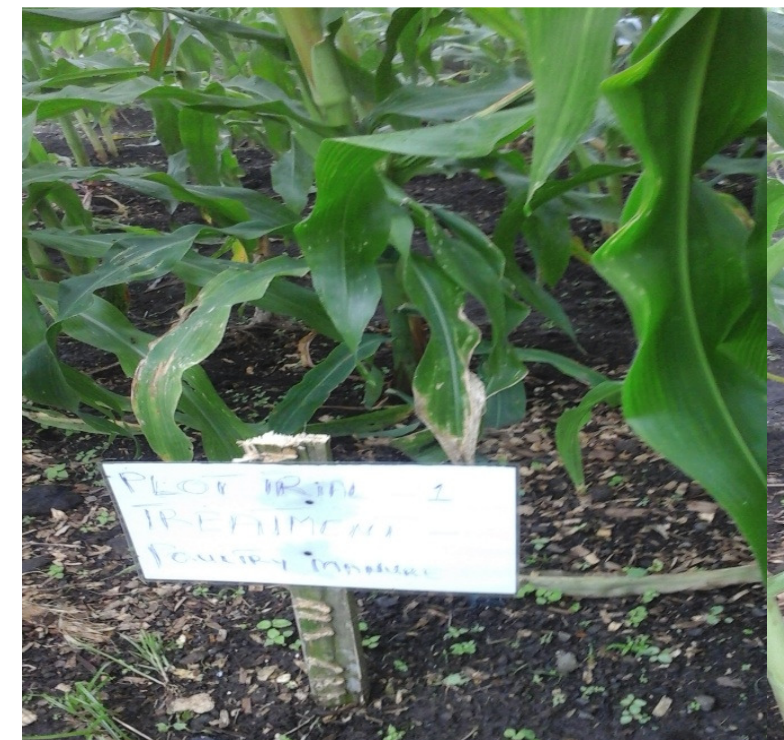

Figure 1: Plot trials label

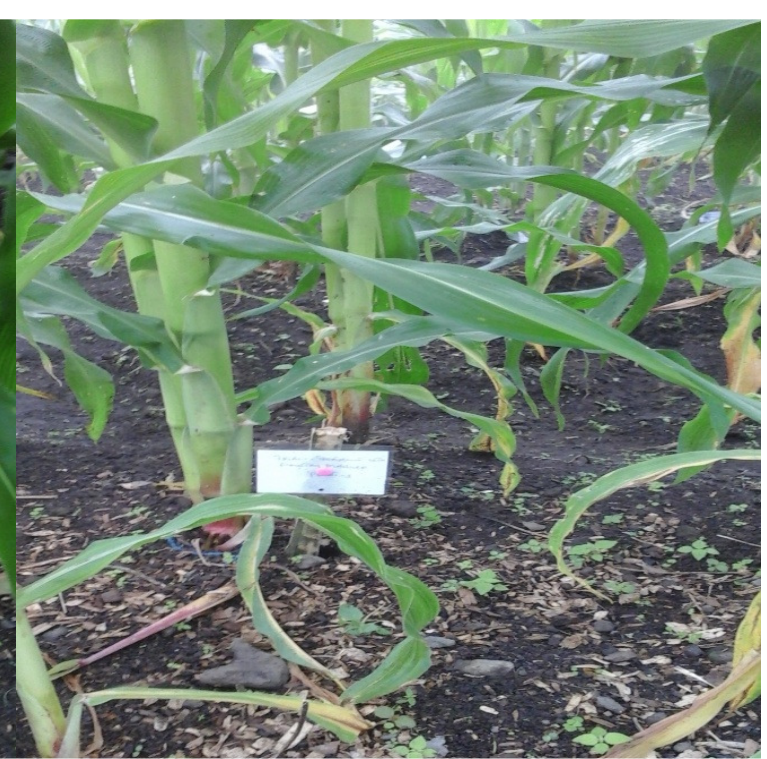

Figure 2: Plants under study

Source: researcher field work gallery

\subsection{Yield and yield related parameters measured}

At maturity, maize was harvested. The maize grain was then air-dried and the dry weight taken and expressed on a $12.5 \%$ water content basis. The number of cobs per plant and the number or rows, per cob were also visually counted. 1000 grans were selected from each treatment an their weight was measured using an electronic balance. 


\subsection{Data analysis}

The data were subjected to analysis of variance using the General Linear Model for a Randomized Complete Block Design to obtain the $P$ value of the effect of the model for each treatment using JMP computer software version 5.1. The significantly different means were separated using Turkey HSD method for pair wise comparison.

\section{RESULTS AND DISCUSSION}

\subsection{Chemical analysis of experimental soil and poultry manure}

Table 1 indicates that the soils of the area are slightly acidic with an average $\mathrm{pH}$ value of 6.1. According to Bohn et al. (1979), $\mathrm{pH}$ conditions between 5.0 and 6.8 are optimal for maize production. This shows that the soils are appropriate for this activity. These soils were of the sandy clay loam textural class. Mengel and Kirkby (1987) reported that sites with high percentage of clay and silt are highly recommended for agricultural practices. Such soils are capable of providing good aeration and retention and supply of nutrients and water. These soils were good in such parameters, predicting high agronomic potentials.

According to Beernaert and Bitondo (1992), the organic matter content was very high $(8.30 \%)$. In the tropics, soil organic carbon is central to sustaining soil fertility on smallholder farms (Swift and Woomer 1993,
Woomer et al. 1994, Asongwe et al., 2016). In low-input agricultural systems in the tropics, it helps retain mineral nutrients ( $N, S, P$ and micronutrients) in the soil and make them available to plants in small amounts over many years as it is mineralized. In addition, soil organic carbon increases soil flora and fauna (associated with soil aggregation, improved infiltration of water and reduced soil erosion), complexes toxic $\mathrm{Al}$ and manganese (Mn) ions (leading to better rooting), increases the buffering capacity on low-activity clay soils, and increases water- holding capacity (Woomer et al. 1994). Continuous cropping, with its associated tillage practices, provokes an initial rapid decline in SOM, which then stabilizes at a low level (Woomer et al. 1994). The nitrogen content of the soils was also very low $(0.18 \%)$ just as the $\mathrm{C} / \mathrm{N}$ ratio. This shows that the rate of mineralization of organic matter is poor. Calcium and $\mathrm{Mg}$ dominate the exchange complex but their concentrations were low $(3.70 \mathrm{cmol}(+) / \mathrm{kg})$ and medium $1.12 \mathrm{cmol}$ $(+) / \mathrm{kg})$, respectively. Continues cultivation of these soils without returning residues depletes these nutrients. Major sources of $\mathrm{Ca}$ in soils include amphiboles, olivine, pyroxene, dolomites and phyllosilicate clay minerals (Todd, 1980). The low values of $\mathrm{Ca}$ in the soils of the study area could be an indication that the aforementioned minerals are not present in substantial amounts. The CEC of the soil was low with a value of $27.2 \mathrm{Cmol}(+) / \mathrm{Kg}$ This could be an indication that these soils have a limited amount of weatherable minerals warranting nutrient application when extensively cultivated.

Table 1: Some physic-chemical properties of soils in the eastern slope of Mount Cameroon before maize experiment

\begin{tabular}{lll}
\hline $\mathrm{S} / \mathrm{N}$ & Concentration & $\begin{array}{l}\text { Description (Beernaert } \\
\text { and Bitondo, 1992) }\end{array}$ \\
\hline $\mathrm{pH}(\mathrm{H} 2 \mathrm{O})$ & 6.1 & Slightly acidic \\
$\mathrm{pH}(\mathrm{KCl})$ & 5.2 & - \\
Sand & 65 & \\
Silt & 13 & Sandy clay loam \\
Clay & 22 & \\
Electrical Conductivity uS/cm & 130 & \\
$\mathrm{CO}(\%)$ & 4.81 & Very high \\
$\mathrm{OM}(\%)$ & 8.30 & Very high \\
$\mathrm{N}(\%)$ & 0.18 & Very low \\
$\mathrm{C} / \mathrm{N}$ & 25 & Poor \\
$\mathrm{Ca}(\mathrm{Cmol}(+) / \mathrm{Kg})$ & 3.70 & Low \\
$\mathrm{Mg}(\mathrm{Cmol}(+) / \mathrm{Kg})$ & 1.12 & Medium \\
$\mathrm{K}(\mathrm{Cmol}(+) / \mathrm{Kg})$ & 0.04 & Very low \\
$\mathrm{Na}(\mathrm{Cmol}(+) / \mathrm{Kg})$ & 0.02 & Very low \\
$\mathrm{CEC}(\mathrm{Cmol}(+) / \mathrm{Kg})$ & 27.2 & Low \\
Available P $(\mathrm{mg} / \mathrm{kg})$ & 94 & High \\
\hline
\end{tabular}




\subsection{Vegetative growth pattern with time}

3.2.1. Plant height with time for the different treatments

The results indicated that during the early days after planting, growth was more rapid in the treatment with pig manure with a height of 23.5 and $37.2 \mathrm{~cm}$ respectively recorded at the third and fifth week, respectively (Table
2). However, as time progressed, growth was slower in the treatment with pig manure while others (NPK, and Poultry manure treatments) accelerated. $\mathrm{R}^{2}$ values of $0.99015>0.98548>0.98056>0.9775$, were obtained respectively for NPK, Poultry manure, pig and Control. This indicates that NPK and poultry manure released nutrients faster in the latter part of the study than the pig manure and control.

Table 2: Maize height time responses to poultry, NPK, Pig and Control soil sample under minimum tillage in S.W. Region Cameroon

\begin{tabular}{lllll}
\hline \multicolumn{5}{c}{ Height/cm } \\
Time/weeks & Poultry & NPK & Pig & Control \\
\hline 3 & 22.36 & 21.84 & 23.5 & 22.6 \\
5 & 39.78 & 37.07 & 37.22 & 34.07 \\
7 & 66.62 & 59.5 & 61.02 & 56.67 \\
9 & 95.48 & 82.22 & 83.27 & 80.26 \\
11 & 123.57 & 110.1 & 98.45 & 97.36 \\
13 & 181.68 & 183.68 & 146.62 & 147.65 \\
\hline
\end{tabular}

\subsubsection{Number of leaves by plant}

Under the different nutritional treatments, the number of leaves from the beginning to the end of the experiment did not differ (Table 3). This indicates that under the presented environmental conditions, the number of leaves could not be used as a major parameter of nutrient influences.

Table 3: Number of leaves on maize plant under different nutrition amendment in the Pan African Institute for Development

\begin{tabular}{lllll}
\hline Time/weeks & Poultry & NPK & Pig & Control \\
\hline 3 & 5.0 & 5.2 & 5.3 & 5.0 \\
5 & 7.5 & 7.0 & 7.0 & 7.2 \\
7 & 9.3 & 8.2 & 8.3 & 8.3 \\
9 & 10.0 & 9.2 & 9.2 & 9.3 \\
11 & 10.6 & 10.0 & 9.4 & 9.4 \\
13 & 12.2 & 11.7 & 10.3 & 11.1 \\
\hline
\end{tabular}

\subsubsection{Stem circumference}

The stem circumference of maize at different stages is shown in Table 4. Poulty manure maintained the largest circumference from the start to the end of the experiment. However, significant deviations were not recorded. 
Table 4: Average stem circumference under different nutritional amendment in the Pan African Institute for Development West Africa Buea

\begin{tabular}{lllll}
\hline \multicolumn{5}{c}{ Circumference /cm } \\
\hline Time in weeks & Poultry & NPK & Pig & Control \\
\hline 3 & 3.5 & 2.9 & 3.1 & 3.2 \\
5 & 5.3 & 4.6 & 4.6 & 4.3 \\
7 & 7.1 & 7.3 & 6.4 & 6.7 \\
9 & 8.6 & 8.8 & 8.2 & 8.2 \\
11 & 9.7 & 9.2 & 8.4 & 8.6 \\
13 & 10.4 & 9.6 & 8.5 & 9.0 \\
\hline
\end{tabular}

\subsection{Final maize growth and yield of various treatments}

Data presented table 5 show that plant height was significantly affected by different treatments. The comparison of treatments' means reveals that maximum plant height $(215 \mathrm{~cm})$ was recorded from plots where poultry manure was applied NPK followed by $210 \mathrm{~cm}$, which was slightly, lower than poultry. Pig manure application and control did not differ significantly from each other with respect to plant height of maize while the control (no treatment) gave minimum plant height. The increase in plant height with poultry manure was attributed to the availability of nutrients in the poultry manure throughout the growing season. These results are in accordance with the findings of Mitchell and Tu (2005) and Warren et al. (2006).

Table 5: Effect of organic and inorganic fertilizers on growth, and yield of maize under minimum tillage on volcanic soils South West Region Cameroon

\begin{tabular}{|c|c|c|c|c|c|c|c|}
\hline Treatments & $\begin{array}{c}\text { Plant } \\
\text { height } \\
\text { (cm) }\end{array}$ & $\begin{array}{l}\text { No. of } \\
\text { Cobs per } \\
\text { plant }\end{array}$ & $\begin{array}{l}\text { No. of rows } \\
\text { per cob }\end{array}$ & $\begin{array}{l}\text { No. of } \\
\text { grains } \\
\text { per row }\end{array}$ & $\begin{array}{l}1000 \\
\text { grain } \\
\text { wt. (g) }\end{array}$ & $\begin{array}{c}\text { Grain } \\
\text { yield } \\
(\mathrm{t} \mathrm{ha-1})\end{array}$ & HI (\%) \\
\hline Control & $172 \mathrm{~d}$ & 1.00 & $8.0 \mathrm{c}$ & $18.1 \mathrm{c}$ & $173 \mathrm{~d}$ & $0.72 \mathrm{c}$ & $13.6 \mathrm{~b}$ \\
\hline Pig Manure & $200 c$ & 1.00 & $10.0 \mathrm{bc}$ & $21.6 \mathrm{~b}$ & $179 d$ & $0.73 \mathrm{c}$ & $15.2 \mathrm{ab}$ \\
\hline NPK & 208 bc & 1.00 & $10.7 \mathrm{bc}$ & $23.1 \mathrm{~b}$ & $201 c$ & $1.2 \mathrm{~b}$ & $16.5 a b$ \\
\hline Poultry Manure & $212 b c$ & 1.00 & $12.0 \mathrm{~b}$ & $27.6 \mathrm{a}$ & $205 c$ & $1.4 \mathrm{a}$ & $17.8 \mathrm{ab}$ \\
\hline $\begin{array}{l}\operatorname{LSD}(5 \%) \\
\text { FMS }\end{array}$ & $\begin{array}{l}16.4 \\
814\end{array}$ & NS & $\begin{array}{l}3.23 \\
3.15\end{array}$ & $\begin{array}{l}3.25 \\
3.20\end{array}$ & $\begin{array}{l}5.3 \\
8.71\end{array}$ & $\begin{array}{c}0.572 \\
0.09\end{array}$ & $\begin{array}{l}4.78 \\
6.90\end{array}$ \\
\hline
\end{tabular}

Means not sharing the same letters in a column differ significantly at $5 \%$ probability.

$\mathrm{NS}=$ Non Significant: $\quad \mathrm{EMS}=$ Error mean square

The maize yields were significantly different $(P<0.05)$ between the four treatments (table 5). On average poultry treatments and NPK gave the highest yields (1.4 and $1.2 \mathrm{~kg} \mathrm{t} \mathrm{ha}^{-1}$ respectively). The control and pig manure gave the lowest yields (average $0.7 \mathrm{~kg} \mathrm{t} \mathrm{ha}^{-1}$ respectively). These results strongly agree with those of Boateng et al (2006), who reported that poultry manure significantly increase yields.

Averagely, the highest number of maize grains (27.6 grains /cob) with an average weight of $205 \mathrm{~g} / 1000$ grains was obtained from the treatment with poultry manure. The least number of grains were obtained from the control treatment with 18.1 grains with 1000 weighing $173 \mathrm{~g}$. This indicates that good nutritional amendment influences both the number and weight of grains produced. The higher the harvest index, the greater was the grain yield.
Higher the harvest index, the greater was the grain yield. Application of different treatments of fertilizer inputs such as poultry manure had significant effect on harvest index table..... The maximum harvest index $(17.8 \%)$ was recorded from maize crop manure at $1.4 \mathrm{t}$ $\mathrm{ha}^{-1}$, which was slightly more than NPK $\left(1.2 \mathrm{t} \mathrm{ha}^{-1}\right)$. The lowest harvest index (13.60\%) was recorded in plot where no manure was applied (control), it was however slightly lower than pig manure treatments.

\section{CONCLUSION}

From the study, it is concluded that the soils of the area were slightly acidic with an average $\mathrm{pH}$ value of 6.1 . The average concentration of calcium and magnesium were low $(3.70 \mathrm{cmol}(+) / \mathrm{kg})$ and medium $1.12 \mathrm{cmol}(+) / \mathrm{kg})$, 
respectively. The average nitrogen content of the soils was very low $(0.18 \%)$ just as the $\mathrm{C} / \mathrm{N}$ ratio. Organic manures and NPK fertilizer when applied differently enhanced availability of soil nutrients. Application of poultry manure on the soils had a significant effect on the growth and yield than NPK fertilizer, and pig manure. Poultry manure fertilization gave the highest yield of $1.4 \mathrm{t}$ ha $^{-1}$ and the maximum harvest index $(17.8 \%)$ while the lowest harvest index of $13.60 \%$ was recorded in plot where no manure was applied (control). The study concludes that though manures enhance productivity under minimal tillage, the type and duration of handling plays a great role in nutrient availability.

\section{ACKNOWLEDGEMENT}

The authors express gratitude to Pan African Institute for Development for giving enough space in their research farm for the experiment.

\section{REFERENCE}

Asongwe GA, Yerima BPK, Tening AS. (2016). Spatial variability of selected physic-chemical properties of soils under vegetable cultivation in urban and periurban wetland gardens of the Bamenda municipality, Cameroon. African Journal of Agricultural Research, 11(2):74-86.

Baudeon F, Mwanza HM, Triomphe B and Bwalya M 2007. Conservation Agriculture in Zambia; A study of the Southern Province African Conservation Tillage. Nairobi, Kenya: Kenya: Centre de Cooperation international de Recherche Agronomique pour le Development, FAO. 138pp.

Bearnaert F, and Bitondo D. 1992. A simple and Practical Method to Evaluate Analytical Data of Soil Profiles. CUDs, Soil ScienceDepartment. Belgia Cooperation Dschand Cameroon, 65PP.

Boateng S, Zickermann AJ and M. Kornaharens (2006). Effect of poultry manure on growth and yield of maize West Africa Journal of Applied Ecology: 9:111.

Bohn, H. L., B. L. McNeal, and G. A. Oconnor. 1979. Soil Chemistry. John Wiley and Sons. New York.329pp.

Cassman, K.G., Dobermann, A., Walters, D.T., Yang, H. (2003). Meeting cereal demand while protecting natural resources and improving environmental quality. Annual Review of Environment and Resources.;28:315-358.

10.1146/annurev.energy.28.040202.122858.

FAO (Food and Agriculture Organization of the United Nations), (2008). FAO fertilizer and plant nutrition bulletin: Guide to laboratory establishment for plant nutrient analysis. FAO, Rome, Italy. 203p.

Giller KE, Witter E, Corbeels, M and Titonell P (2009). Conservation Agriculture and smallholder farming in Africa: The Heretics View. Crops Research 2009.
Doi:10.1016/j.fcr.2009.06.017,1-12.

Gowing JW and Palmer M (2008). Sustainable Agriculture Development in Sub-Saharan Africa: The case of a Paradigm Shift in Land Husbandry. Soil use and Management 24:92-99.

Mengel K, Kirkby EA (1987). Principles of plant nutrition. International Potash Institute. Worblaufen-Ben Switzerland, $687 \mathrm{pp}$.

MINEPAT: Cameroon Ministry of Planning and Regional Development (2008). Growth and employment strategy paper. Ministry of Planning and Regional Development, Yaounde Cameroon.

Mitchell CC, and Tu S (2005). Long-term evaluation of poultry litter as a source of nitrogen for poultry litter as a source of nitrogen for cotton corn. Agronomy Journal 97:399-407

Mucheru-Muna M, Mugendi D, Kung'u J, Mugwe J, Bationo A. (2006). Effects of organic and mineral fertilizer inputs on maize yield and soil chemical properties in a maize cropping system in Meru South District, Kenya. Springer Science+Business Media B.V.

Ndam LM, Enang. JE, Mih AM, and Egbe AE (2014). Weed diversity in maize (Zea mays L.) fields in South Western Cameroon international Journal of current Microbiological and Applied Sciences. ISSN: 2319-7706 Volume 3 Number 11 (2014) pp. 173-180

Palm CA, Myers RJ, Nandwa SM. (1997). Combined use of organic and inorganic nutrient source for soil fertility maintenance and replenishment. In: Buresh, R. (eds.), Replenishing Soil Fertility in Africa. SSSA Special Publication No 51. Wisconsin, USA. Pp 193 $-217$.

Pauwels, J. M., Van Ranst, E, Verloo M, Mvondo Ze, A (1992). Méthodes d'analyses de sols et de plantes, équipements, gestion de stocks de verrerie et de produits chimiques. Universite de Dschang Cameroun, 1215pp.

Sanchez P A, Jama BA, in Integrated Plant Nutrient Management in Sub-Saharan Africa: From Concept to Practice , Vanlauwe B, Diels J, Sanginga N, Merckx R, Eds. (CABI, Wallingford, UK, 2002), pp. 23-45; P. A.

Stoorvogel JJ, and Smaling EMA (1990). Assessment of soil nutrient depletion in sub- Saharan Africa: 19832000.

In: Kayuki ${ }^{\mathrm{a}}$ K.C. and Wortmann CS. (2001). Plant materials for soil fertility management in sub humid tropical areas. Agronomy journal 93:929-935 (2001).

Swift MJ, and Woomer P (1993). Organic matter and the sustainability of agricultural systems: Definition and measurement. In K. Mulongoy and R. Merckx (eds.) Soil Organic Matter Dynamics and Sustainability of Tropical Agriculture. Chichester, U.K.: Wiley-Sayce. Pp. 3-18

Todd DK (1980). Groundwater Hydrology. John Willey and Sons. New York, 535 pp.

Vanlauwe B, Diels J, Sanginga N, Merckx R (2002). 
Integrated Plant Nutrient Management in Subsaharan Africa: From Concept to Practice. Wallingford Oxon, UK CAB International, 352 pp. WHO (2002). The World Health Report, Reducing risks, promoting health. Geneva World Health Organization, $172 \mathrm{pp}$.

Warren J G, Phillips SB. Mullins GL, Keahey K, and Penn CJ (2006). Environmental and production consequences of using alum-amended poultry litter as a nutrient source for corn. Journal of Environmental Quality 35:172-182.

Waseem, K, Kamran, Q. M, Jilani, M.S. (2008). Effect of different levels of nitrogen on the growth and yield of Cucumber (Cucumis sativus L.). J. Agric. Res., 46: $259-266$.
Woomer PL, Martin A, Albrecht A, Resck DVS, and Scharpenseel HW (1994). The importance and management of soil organic matter in the tropics. In P.L. Woomer and M.J. Swift (eds.), The Biological Management of Tropical Soil Fertility. Chichester, U.K.: Wiley-Sayce. Pp.47- 80.

Woomer PL, Martin A, Albrecht A, Resck DVS, Scharpenseel HW (1994). The importance and management of soil organic matter in the tropics. In Woomer PL, Swift MJ. (eds.), The Biological Management of Tropical Soil Fertility. Chichester, U.K.: Wiley-Sayce, pp. 47- 80.

Yu-kui R, Yun-feng P, Zheng-rui W,. Jian-bo S (2009). Stem perimeter, height and biomass of maize (Zea mays L.) grown under different $\mathrm{N}$ fertilization regimes in Beijing, China. International Journal of Plant Production

Cite this Article: Sallah A, Azinwie AG, Alobwede NJ, Ngang FD (2017). Effect of different Organic Manures and Mineral NPK Fertilizer on Maize Yield on Volcanic Soils of the Mt Cameroon area under Minimum Tillage. Greener Journal of Agricultural Sciences, 7(4): 097-104, http://doi.org/10.15580/GJAS.2017.4.051617062. 